\title{
The UK New Regulatory Framework of High-Cost Short-Term Credit: Is There a Shift Towards a More "Law and Society" Based Approach?
}

\author{
Abdul Karim Aldohni ${ }^{1}$ \\ Received: 10 November 2016 / Accepted: 26 April 2017 / \\ Published online: 22 June 2017 \\ (C) The Author(s) 2017. This article is an open access publication
}

\begin{abstract}
In the wake of the 2008 financial crisis, the consumer credit market in the UK has witnessed a proliferation in the number of high-cost short-term credit (HCSTC) providers promising easy access to credit without the complications of credit history. This act of generosity came at a very high price, which on some occasions reached $4000 \%$ APR. After refusing for many years to interfere with the credit price and other aspects of the HCSTC business' practices, the Government since 2014 started to impose certain regulatory restrictions on the sector including a cost cap, January 2015, on what HCSTC providers can charge. This article argues that the FCA's credit cost cap and other regulatory measures taken since 2014 signify an important shift in the regulatory approach to HCSTC. It argues that the neoliberal 'law and economics' theoretical paradigm is no longer the foundation of the regulatory framework. Instead, the Government has shifted towards a Polanyian 'law and society' based approach, which is attentive to the vulnerability of HCSTC consumers and consequently more capable of protecting them. This article concludes by arguing how this newly adopted approach can be further advanced.
\end{abstract}

Keywords Vulnerable consumers · High-cost short-term credit · Credit consumer protection · Neoliberalism · Embeddedness · Credit cost cap · Consumer Credit Act 1974 - Financial Conduct Authority (FCA) · Financial Services Act 2012

The financial crisis of 2008 was a defining event of the first decade of the twenty-first century. It brought significant changes to financial structures at both global and domestic levels and triggered a chain of economic and social events such that its impacts are still unfolding.

In the UK, for example, the model of a sole financial regulator failed its most difficult test, namely preventing the 2008 financial crash, and proved to be ineffective. As a result, the UK's

Abdul Karim Aldohni

a.k.aldohni@ncl.ac.uk

1 Newcastle Law School, Newcastle University, Newcastle upon Tyne, UK 
financial regulatory structure was redesigned and new regulatory bodies were introduced with the intention of avoiding the mistakes of the past. This new regulatory structure is yet to be tested. The UK financial market also witnessed certain unexpected episodes, for instance, the disappearance of some of its main regional players, such as Northern Rock in the North East of England that was fully nationalised and then sold to Virgin Money (Goff 2012), the partial nationalisation of some of the major institutions in the banking market such as the Royal Bank of Scotland and the break-up of some of the large banking institutions such as Lloyds TSB.

In addition to changing structures, more stringent banking requirements were introduced by mainstream lenders before advancing credit to consumers, with the result that individuals' access to conventional borrowing was restricted. This led, importantly, to a proliferation of a particular type of high-cost credit, known as high-cost short-term credit (HCSTC), which includes payday loans (FCA 2016b, c). The providers of this type of high-cost credit promise easy access to credit without the complications of credit history; however, this comes at a cost.

HCSTC providers are notorious for their annual percentage rate (APR) which was, not so long ago, soaring over $4000 \%$. Although it does not include default charges, the APR calculation factors certain variants into the total cost of credit including the interest rate and other payable charges (The Consumer Credit (Total Charges for Credit) Regulations 2010 (SI 2010/1011), para 4 [5a] and para 6). While this phenomenon has not gone unnoticed by the regulator, the regulatory response was delayed by the re-organisation of the financial regulatory authorities. As of 1st April 2014, one of the newly established financial regulators, the Financial Conduct Authority, took over the responsibility for consumer credit regulation from the Office of Fair Trading (OFT). The FCA was empowered by s.24 of the Financial Services Act 2012 (substitutes sections 138-164 FSMA 2000 and inserts in the FSMA2000 s137C) to make rules regarding the cost of credit and duration of credit agreements. Further, s.131 of the Financial Services (Banking Reform) Act 2013 amended section 137C of the Financial Services Market Act 2000 placing a duty on the FCA to protect HCSTC consumers against excessive charges, in other words, a duty to introduce a price cap.

In preparation for its new responsibility, the FCA in October 2013 issued a Consultation Paper (CP) entitled "Detailed Proposal for the FCA Regime for Consumer Credit," in which the FCA provided its vision for the governance of the HCSTC market. More importantly, this $\mathrm{CP}$ represented a measured response to the key problems that were identified in the OFT's "Payday Lending Compliance Review: Final Report" (2013), which included the use of multiple loans roll over, irresponsible lending and the lack of affordability checks (OFT 2013). Some of the key measures proposed in the FCA's October 2013 consultation included capping debt roll over to two times, requiring risk warning on HCSTC financial promotions, requiring HCSTC providers to provide information on free debt advice before the point of rollover and capping the price of HCSTC. The first four measures were implemented on 1st July 2014 (FCA 2014c), while the price cap was later subject to a separate consultation (FCA 2014b) and was implemented on 2nd January 2015 (FCA 2014a). In addition, since taking over the regulation of consumer credit, the FCA has included specific binding rules in its Consumer Credit Sourcebook, Chapter 5 (CONC 5), with regard to responsible lending, credit worthiness and affordability assessment that apply to HCSTC (FCA 2016d).

The article is pursuing two main arguments. First, it argues that the recent regulatory measures brought by the FCA to the HCSTC sector do not only represent a regulatory shift but also an ideological one. The article demonstrates that for a long period of time, the legal and regulatory approach to HCSTC was primarily influenced by a "law and economics" paradigm and its neoliberal underpinning. Accordingly, it is argued that this approach prevented the 
regulator from interfering to prevent the abusive practice of HCSTC providers, which adversely affected a vulnerable segment of the society. The article contends that the recent regulatory changes to the HCSTC market signify a clear departure from a "law and economics" based regulatory approach. It is, therefore, argued that there is a shift towards a more "law and society" based regulatory approach in which the interest of the society is not subordinated to the economy. Central to article's analysis of the "law and society," paradigm is Polanyi's concept of "embeddedness" that re-defines the relationship between the society and the market, where the former is not treated as an "adjunct" to the latter.

Second, the article argues that despite the significance of these new regulatory measures, they are still unable to address all the challenges posed by the HCSTC phenomenon. The article suggests that these newly brought regulatory measures are an essential part of the infrastructure of an embedded HCSTRC market. However, there are other important measures that the UK government needs to take in order to effectively move away from the influence of neo-liberalism and further embed the HCSTC market in the society.

In order to achieve its objectives, the article in part I examines the origins of the UK highcost credit sector in general and the evolution of HCSTC as one of its main segments. This part is essential to highlight the significant challenges that the HCSTC sector poses. In part II, the article reviews the underpinning theoretical foundation of the legal and regulatory framework that governs the HCSTC sector in order to demonstrate the ideological shift in the regulatory approach. In part III, the article examines the steps that need to be taken by the government to further embed the HCSTC in the society.

\section{The Origins of the High-Cost Credit Sector in the UK and the Evolution of High-Cost Short-Term Credit}

Money has not always been an essential component of all individuals' daily financial transactions. Adam Smith argued that money gained its prominent position only when barter ceased to exist (Smith 2008). Smith found that the "market" created the required environment in which commodities are exchanged for money and then the same money is used to purchase other commodities. Hence, the quantity of money received from the exchange decides the quantity of the other commodities that can be purchased. Since then, accordingly, money became an essential instrument to estimate the value of commodities offered on the market (Smith 2008). Further, an individual's revenue is estimated on the basis of the power of purchasing and consuming that is offered by the quantity of money he or she receives on an annual basis (Smith 2008). This significant shift in the eighteenth century made the cash nexus central to market activities. For many nineteenth century classical political economy critics, the cash nexus itself represented the axiomatic characteristic of modern market exchange (Finn 2003). More importantly, since money became an integrated part of almost all transactions, a new market, namely consumer credit market, emerged to facilitate the modern form of market exchange. The consumer credit market is primarily used by individuals who do not have the required quantity of money to purchase the needed quantity of goods.

Within this consumer credit market, there has always been the high-cost credit market, which was mainly associated with a large segment of the working class in the UK. Historically, this has always been a case due to a number of factors among which were a low and irregular income combined with instability of employment (Johnson 1983; Tebbutt 1983). These problems created a constant need among this social class to find alternative sources of credit in order to make ends meet. 
It is worth noting that the UK high-cost credit market has continuously evolved throughout the centuries. The nineteenth century (1850-1900) witnessed the emergence of several modes of high-cost credit - such as pawnbroking, mail order, hire purchase, credit drapers and check traders - to satisfy the economic needs of an economically vulnerable segment of the society (O’Connell and Reid 2005). Pawnbroking had particularly flourished during the nineteenth century where the largest share of the high-cost credit market belonged to pawnbrokers, and pawning accommodated the credit needs of the working class (Tebbutt 1983).

The twentieth century witnessed certain changes to the high-cost credit market with the sharp decline in pawnbroking (Taylor 2002) and the gradual disappearance of credit traders and check traders (O'Connell and Reid 2005). Moreover, some early forms of HCSTC started to emerge with the rise of doorstep moneylenders such as Provident (O'Connell 2009). This exposed this economically vulnerable segment of society to the increasing business of moneylenders. Since then, the business models of moneylending evolved, but its exploitive nature has never changed; whether in the form of a money shop or a doorstep lender, those moneylenders have always been actively present in economically disadvantaged areas (O’Connell 2009). ${ }^{1}$

In the twenty first century, a new breed of moneylenders has evolved and proliferated, namely online HCSTC providers (the like of Wonga, Quick quid and Pound to pocket). They maintained the promise of a quick and easy access to credit for consumers with a weak bargaining position while charging them an astronomic interest rate. ${ }^{2}$

The development of these online HCSTC providers raises serious social and economic concerns, which compound already existing concerns with HCSTC lending.

First, being accessible on smart phone apps or online widens HCSTC provides' client base, expanding especially among younger generations (i.e., computer savvy/smart phone generation). Therefore, the traditional stereotype of moneylenders' clients as working class family men/women is no longer a complete accurate reflection of reality. A report published by R3: Association of Business Recovery Profession in 2013, for example, showed that the demand for HCSTC among young adults - aged 18 and over-is "worryingly high" (R3: Association of Business Recovery 2013). Moreover, a relatively recent survey in 2014 showed further that a "worrying" number of undergraduate students use HCSTC lenders (BBC 2014). The danger with attracting this group of borrowers is that their use of this type of credit is not always associated with economic hardship and a need to cover the costs of necessities, but rather with consumerism and conspicuous consumption. ${ }^{3}$ In this regard, a series of studies has demonstrated that the increased propensity to use credit is primarily driven by individuals' tendency to express their identity through consumption and social comparison (Kamleitner et al. 2012). The acquisition of credit in the twenty first century, therefore, can be a means to an end that is the unaffordable goods, which are needed in order to establish social status among their peers (Kamleitner et al. 2012). It has been suggested that in many cases, the increased use of credit is

\footnotetext{
${ }^{1}$ For more recent examples, please see Bureau of Investigative Journalism https://www.thebureauinvestigates. com/2014/03/12/uk-one-short-term-lender-for-every-seven-banks-on-the-high-street/.

${ }^{2}$ Before the FCA price cap came into effect 2 January 2015, Wonga was charging 4214\% Annual Percentage Rate (APR) which meant $31.37 \%$ interest rate per month.

${ }^{3}$ It is defined by Mason as a "form of exceptional behaviour .... concerned primarily with the ostentatious display of wealth. Motivated by a desire to impress others with the ability to pay particularly high prices for prestige products, it is a form of consumption which is inspired by the social rather than the economic or physiological utility of products" see Mason, R. (1981). Conspicuous consumption: A study of exceptional consumer behaviour. Aldershot, UK: Gower pp. vii-viii.
} 
socially motivated and that during a period of economic hardship and increased income inequalities, such social pressure tends to increase (Kamleitner et al. 2012).

Second, and more importantly, the online nature of this type of high-cost credit providers has dehumanised the lending transactions and removed a community link. The traditional forms of HCSTC providers, such as money shops and doorstep lenders, have always depended in their business on their agents who have their links and ties with the community among which they operate. HCSTC providers (or their agents) showed, on a few occasions, genuine acts of human compassion as they prevented a debtor from taking further credit knowing that they would not be able to pay it back, or allowed a distressed debtor to miss a payment (O’Connell and Reid 2005). ${ }^{4}$

The human interaction, consideration and community understanding aspect of lending are currently missing from all online HCSTC lending transactions, which simply rely on an algorithm, a software or a credit rating calculation to make an immediate lending decision. The automated mechanical nature of these lending decisions, compounded by lax affordability checks (OFT 2013) ${ }^{5}$ and the lack of reflection time for consumers due to the instantaneous access to this type of credit, have significantly disadvantaged those consumers with, for one reason or another, a weak bargaining position.

The important narrative that the above overview provides is that the substratum of HCSTC business has not actually changed. Regardless of the form in which HCSTC providers are reaching out to consumers, "vulnerability" of their consumers continues to be a defining feature of their business.

The concept of vulnerability is of particular significance in the financial context. Although being on low income is not "a necessary condition of vulnerability," it is an essential cause of it and when combined with other vulnerabilities - such as young age and naivety, lack of literacy skills, life events or illness - those affected consumers become highly susceptible to significant detriment (FCA 2015; FCA 2016a). In other words, vulnerable consumers are those who are exposed to one or more of the above limiting factors, which undermine their bargaining position and well-being (Smith and Cooper-Martin 1997).

Moreover, it has been suggested that the way in which modern markets operate adds further to the vulnerability of consumers (FCA 2015). For instance, the new online platform, which the new breed of HCSTC providers use, has not only provided them with wider potential groups to prey on, but it also weakened consumers bargaining powers given the automated nature of the process and the lack of any human interaction.

These changes in consumer base and methods of offering are alarming, and they require a shift in the regulatory approach to this type of credit and its providers.

\section{The Theoretical Makeup of High-Cost Short-Term Credit Legal and Regulatory Framework}

Uncovering the theoretical underpinning of the governing framework of the UK HCSTC market not only helps understand its remits and shortfalls, but also helps identify ways to

\footnotetext{
${ }^{4}$ O'Connell cites a different number of studies that show that money lenders and their agent were concerned with establishing a trust and friendship relationship with their customers and refer to a number of occasions where this was manifested in actions.

${ }^{5}$ In the OFT final report (2013), there is evidence of the lack of sufficiency and rigour in assessing credit worthiness and affordability by the majority of short-term lenders (p.12).
} 
promote and better develop this governing framework. In this respect, there are two distinctive theoretical frameworks, namely "law and economics" and "law and society," 6 that are of significant relevance to HCSTC and should be examined in this context.

\section{Reviewing HCSTC Governing Structure through the Lens of the "Law and Economics" Framework}

It can be argued that, until very recently, the legal and regulatory framework governing the HCSTC sector has been primarily influenced by the "law and economics" theoretical framework. This means that the governance of the UK HCSTC sector has been predominantly driven by neoliberal economic thought (Ramsay 2010; Ramsay and Williams 2009) ${ }^{7}$ and shaped by Hayek's free market ideology and New Institutional Economics (Haldar 2014). ${ }^{8}$

Harvey (2005) defines neo-liberalism "as a theory of political economic practices' that closely associates human wellbeing with the liberation of the individual entrepreneurial freedoms and skills" (Harvey 2005, p. 2). This, accordingly, requires a set of preconditions that are strong private property rights, free markets, free trade and a State that can preserve these preconditions (Harvey 2005). Further, it has been suggested that one of the key characteristics that distinguishes neoliberalism from the other liberal projects is its "market centrism" (Mudge 2008, p. 714). Neo-liberalism, therefore, severs the market's links with other entities and elevates the market above all. This form of the market as a self-dependent entity, according to neo-liberalism, symbolises the source of human freedom (Mudge 2008).

The "market centrism" premise can be traced in the writing of one of the most eminent neoliberal thinkers, Friedrich von Hayek (Harvey 2005).

Hayek considers a free and competitive market a manifestation of a "spontaneous order" that is society and, more importantly, a major tool in creating such an order (Hayek 1988, pp. 6-7). Therefore, Hayek argues against any "interference" or "intervention" in the market in the form of central collective commands that require specific actions (Hayek 1973, p. 51). This is due to the fallibility of the premise of such mechanism, namely the ability of a central authority to have the required knowledge and information of all the elements and their changing factors in the market order (Hayek 1988, p. 7). Instead, Hayek favours a selfregulating market, "highly complex self-maintaining orders" (Hayek 1988, p. 9), in which the elements of the order adjust in actions to new factors (Hayek 1973) primarily through the mechanisms of competition and pricing (Hayek 1994). ${ }^{9}$ However, he found "a dogmatic laissez faire" (Hayek 1994, p. 41) market to have tainted the liberal cause (Hayek 1994, p. 21). Hence, Hayek stresses the need for "rules" of conduct that assist the formation of the

\footnotetext{
${ }^{6}$ Both theoretical frameworks were originally examined by Haldar in the context of law and development. Haldar, A. (2014). Law and development in crisis: An empirical challenge of the current theoretical frames. Northern Ireland Legal Quarterly, 65(3) 303-321.

${ }^{7}$ Christopher Payne has examined the history of neo-liberalism and its influence on the politics of consumers and credit in the UK, see Payne, C. (2012) The consumer, credit and neoliberalism: Governing the modern economy. London: Routledge. Walker examined the links between increased personal debt and neo-liberal economic policies in the UK see Walker, C. (2011). Personal debt, cognitive delinquency and techniques of governmentality: Neoliberal constructions of financial inadequacy in the UK. Journal of Community \& Applied Social Psychology, 22, 533-538.

${ }^{8}$ Considering that the focus of Haldar's article was "law and development" she includes the "Rule of Law Orthodoxy" as well, see Golub, S. (2003). Beyond rule of law orthodoxy, the legal empowerment alternative. Vol. 41. Washington: Carnegie Endowment for International Peace.

${ }^{9}$ see also footnote n6 in Haldar 2014.
} 
"self-organising structure" of the market order (Hayek 1988, p. 37) and only guide the interactions of individuals (Hayek 1973, p. 49). The free market as envisaged by Hayek is a space in which individuals' interaction is guided by a minimum set of rules, rather than commands, that is offered by a "free society" (Hayek 1978, p. 82) and creates conditions under which individuals' knowledge and initiative can be utilised (Hayek 1994, p.40). This suggests that the market as an entity is separate from society and that these rules, which are offered by social organisations, are extrinsic to the market and not social in nature (Haldar 2014).

Furthermore, in its quest to liberate "individual entrepreneurial freedoms and skills," neoliberalism brings focus to the institutional framework within which this aspired process of liberation can be achieved (Harvey 2005, p. 2). It proposes that one of the essential characteristics for this framework, in addition to free markets, is strong private property rights. It also envisages a limited role for the State in order to maintain these preconditions, i.e., free markets and private property rights (Harvey 2005). In this regard, the "New Institutional Economics" $(\mathrm{NIE})^{10}$ has focused on further advancing the neo-liberal quests in this respect.

Out of the four levels of social analysis discussed by Williamson (2000), ${ }^{11}$ NIE only advances the "institutional environment" and the "institutions of governance" (Williamson 2000 , p. 598). The former concerns the protection of property rights due to their economic significance, and the latter is mainly concerned with installing the required mechanisms that are capable of protecting these property rights and settling any related disputes (Williamson 2000). In this regard, it has been suggested that "one of the purposes of the legal system is to establish that clear delimitation of rights on the basis of which the transfer and recombination of rights can take place through the market" (Coase 1959, p. 25).

Accordingly, government's involvement in the market should be limited to introducing the above mentioned legal framework and protecting its enforceability, while the market is left with the task of re-assigning property rights according to the supply and demand mechanism and pricing (Golub 2003).

Leading from the above discussion, it can be argued that - up until 2014 where the regulator (FCA) started to interfere in the HCSTC market by imposing a set of protective measures the latest of which came into effect in January 2015 by capping the HCSTC cost - a close link could be established between certain aspects of the UK's regulatory approach to the HCSTC sector and some of the fundamental premises of the "law and economics" theoretical framework, to which we turn now.

The strong influence of neoliberal economic policies goes back to the late 1970s where the consumer credit market in the UK, among other segments of the financial sector, witnessed significant changes to its governance ethos. With regard to consumer credit, the Government of the time established the Crowther Committee to review the governance of the consumer credit sector. The report, which was published in 1971, showed clear signs of a neoliberal approach to regulating consumer credit. It stated that "the right policy is not to restrict their [consumers'] freedom of access [to credit] by administrative and legal measures but to help the minority who innocently get into trouble to manage their financial affairs more successfully" (Crowther Report 1971, para 3.9.2). It is the neoliberal assumption that consumer credit, especially for those with low income, is beneficial as it helps fill the financial gaps between

\footnotetext{
${ }^{10}$ For more detail on the evolution of NIE, see Richter, R. (2005). The new institutional economics: Its start, its meaning, its prospects. European Business Organisation Law Review, 6 (2) 161-200.

${ }^{11}$ Level 1: embeddedness, Level 2: institutional environment, level 3: governance of the game, Level 4: resource allocation and employment, see Williamson, O. E. (2000). The new institutional economics: Talking stock, looking ahead. Journal of Economic Literature, 38(3), 597.
} 
individuals' income and expenses and also allows them to accumulate assets in the long run. Trumbull (2014) describes this approach to consumer credit as a form of privatisation to the welfare regime (Trumbull 2014).

More importantly, the report sets the tone for many years to come with regard to the level of State intervention that is expected in the consumer credit market. It stated: "our general view is that the state should interfere as little as possible with the consumer's freedom to use his knowledge of consumer credit market to the best of his ability and according to his judgement of what constitutes his best interest...., it remains a basic tenant of a free society that people themselves must be the judge of what contributes to their material welfare" (Crowther Report 1971, para 3.9.1). In practice, it meant that the State should no longer be involved in how credit is allocated; it should be left to the consumers on one side and to the credit providers on the other to handle this process. This maps onto Hayek's premise of self-regulating market that is free from any central collective interventions and predominantly relies on a pricing mechanism to maintain its order.

In response to these neoliberal propositions, the Consumer Credit Act (CCA) was first introduced in 1974. It is important to note that the CCA 1974 applies to all types of consumer credit including high-cost credit, in which HCSTC is one of its forms.

The Act, since its introduction, abandoned the statutory ceiling of interest $48 \%$, which was set by the Money Lenders Act 1900 that was later amended by the Money Lenders Act 1927, and instead provided the court with discretionary power to intervene when the credit bargain is "extortionate" (Consumer Credit Act 1974, s137-140). Advocates of this shift, for instance Cayne and Trebilcock (1973), highlighted the danger of relying on an interest rate cap. They argued that such a measure would result in a collective exit of lenders from the market and that borrowers will have less access to credit, which would make them face serious "exclusionary" consequences (Cayne and Trebilcock 1973, p. 414). Cayne and Trebilcock (1973) further suggested that such solution "is not only naïve, it clouds the relevant issues by framing an economic problem in moralistic terms" (Cayne and Trebilcock 1973, p. 400).

It must be noted that the idea of a self-regulating consumer credit market in which the price is only determined by the market forces continued until January 2015 to be an accurate reflection of the HCSTC market in the UK. The HCSTC lenders in the UK market were allowed to charge an extortionately high interest rate without being restricted by the regulator at the time, the Office of Fair Trading (OFT).

To the contrary, the OFT in its 2010 "Review of High Cost Credit" took the view that any imposed price control would have adverse effects on consumers and the market despite many consultation respondents requesting a cap on the price of credit (OFT 2010a, b). This was a reflection of a long standing view of the Government of the time. The former Department of Trade and Industry (DTI) in its 2003 White Paper, "Fair, Clear and Competitive: The Consumer Credit Market in the $21^{\text {st }}$ Century," expressed the Government's concerns about the protection of consumers on low incomes. However, the focus of the White Paper was not on the interest rates charged under these credit agreements as the interest rate in general was not viewed as a source of concern. Instead, the White Paper expressed concerns regarding other elements such as default charges, level of security required and lack of transparent information (DTI 2003).

The justification provided by the industry, and clearly accepted by the Government, for charging an extortionately high interest rate stemmed from the fundamental mechanism of pricing. This is simply because the price that was decided by the market factored the higher credit risk, which those lenders were exposed to when lending to less creditworthy consumers. This allowed their APR to reach as much as $4000 \%$ where HCSTC providers enjoyed high discretion in modelling credit risk and factoring it into their APR calculation. 
Additionally, with neoliberalism strongly advocating the protection of private property rights, the influence of NIE can be seen with regard to the governance of the HCSTC market in the UK. In this regard, with the absence of any regulatory restraints on the price of this type of credit, disadvantaged consumers only had one legal means, the CCA 1974 (as amended by CCA 2006), to fall back on.

As mentioned earlier, the CCA 1974, after scrapping the 48\% statutory interest rate cap, introduced the "extortionate credit" bargain test as a means to question the charged interest rate among other elements of the agreement. It is a test that the Government later questioned its effectiveness as a protection mechanism (DTI 2003, p. 52). Accordingly, the CCA1974 was amended by the CCA 2006, which repealed ss137-140 of the CCA 1974 and the "extortionate credit" bargain test, and introduced a new test, the "unfair relationship" test, under ss140A140C (CCA1974).

In assessing the fairness of the agreement, the new test applies to the main credit agreement and any other related agreements ${ }^{12}$ covering the terms of these agreements, their enforcement and actions and omissions by the creditor, or on their behalf, either before or after the making of the credit agreement or any related agreement (CCA 1974, s 140A (1-a, 1-b)).

Since the CCA 2006 amendments came into effect, the courts, regardless of their different place in the judicial hierarchy, have reviewed several credit agreements where the fairness of these contracts was questioned due to the high interest rate charged. ${ }^{13}$ The common theme of the courts' decisions in these cases was the primary focus on the market practice to decide whether the high interest rate would render the agreement unfair. This can be seen in the High Court and the Court of Appeal decisions in Khodari $v$ Al Tamimi [2009] EWCA Civ 1109, Barons Finance Ltd. v Lara Basirat Abeni Olubisi [2011] EWCA Civ 1461 and Robert Shaw v Nine Regions Limited [2009] EWHC 3514 (QB), and County Courts decisions in Nine Regions (t/a Logbook Loans) v Sadeer Bromley County Court, Case No: 8QT25415 and Nine Regions (t/a Logbook Loans) v Fateh Singh Leeds County Court, Claim No: 8QZ 16394.

This is not to say that the court does not acknowledge the link between unfairness and extortionate interest rate, but rather to demonstrate the importance that court attaches to the market practice when deciding on the fairness of the interest rate.

The relatively recent decision of the Supreme Court in Pelvin v Paragon Personal Finance Ltd. and another [2014] 1 W.L.R. 4222 has stressed this point by stating that "the view that a court takes of the fairness or unfairness may legitimately be influenced by the standard of commercial conduct" (Pelvin v Paragon Personal Finance Ltd. and another 2014, p. 4230). However, the Supreme Court has balanced the importance of "the standard of commercial conduct" with the court's discretion in deciding the fairness of the agreement, which is "a matter for the court, on which it must make its own assessment." The court will have "a wide range of considerations" which includes "the characteristic of the borrowers...sophistication or vulnerabilities...the range of choices available..." (Pelvin v Paragon Personal Finance Ltd. and another 2014, p. 4231).

Therefore, it can be suggested that the way in which that the unfair relationship test was applied by the court, up until Pelvin (2014), is highly influenced by the "market centrism" premise of the "law and economics" theoretical frame, with its neoliberal bedrock.

\footnotetext{
${ }^{12}$ Defined in Consumer Credit Act 1974, s140C (4-a, b, c) and s140C (7-8).

${ }^{13}$ It is important to note that not all these cases concerned HCSTC agreements. For a detailed discussion of following cited cases and their decisions please see Aldohni, AK. (2013) Loan sharks v. short-term lenders: How do the law and regulators draw the line? Journal of Law and Society, 40(3), 436-441.
} 
Further, the influence of the "law and economics" theoretical frame can be seen in other aspects of the governance of the HCSTC market in the UK.

First, the governance of loans roll over in HCSTC, which is an area where the regulator never interfered and left it for the contracting parties. This practice escalated charges, and as a result, many HCSTC borrowers became debt trapped as their loans became unaffordable (OFT 2012). The OFT "Payday Lending Compliance Review: Final Report” (2013) estimated that $50 \%$ of the sector's revenue came from loans rolled over or refinanced. It was also reported that HCSTC lenders often encouraged rolling over loans, and in some cases, it was found to be a "feature" of the loan (OFT 2013, p.14-15).

Second, the creditworthiness and affordability assessment was not subject to clear rules that must be applied by the HCSTC lenders. The regulator at the time, the OFT, only provided guidance on what constitutes irresponsible lending practices for the purpose of s25 (2B) of CCA 1974. The lack of sufficiency and rigour in assessing creditworthiness and affordability by the majority of HCSTC lenders was identified as one of the major problems in this market (OFT 2013, p. 12).

The lack of regulatory intervention in this respect can be mapped onto the "law and economics" paradigm. More specifically, NIE aspires to limit the legal intervention in the market only to the protection of property rights and the enforceability of the related agreements. In other words, law only ensures the functioning of the market and its mechanisms without being concerned with the social backdrop of that market.

\section{Reviewing HCSTC Governing Structure through the Lens of the "Law and Society" Framework}

The "law and society" theoretical frame offers a unique take on the interaction between law and economy as it reviews their relationship from a sociological perspective. Accordingly, society does not only play an imperative role in shaping this relationship but also, to a certain extent, takes precedence over law and economics. Further, subscribers to this theoretical frame even aspire to develop a new field known as the "economic sociology of law," which is "a sociological analysis of the role of law in economic life" (Swedberg 2003, p. 1).

As this article argues that the "law and economics" theoretical frame is no longer the appropriate foundation of HCSTC regulation in the UK, it is essential, therefore, to examine the influence of the "law and society" paradigm in this context.

In this regard, it can be suggested that the work of Max Weber (1864-1920) and, more importantly, Karl Polanyi (1886-1964) represents the foundation of the "law and society" paradigm. This makes their work of significance to the argument concerning the "law and society" paradigm and its influence on HCSTC regulation in the UK.

Max Weber was one of the leading sociologists who brought sociology closer to economics demonstrating the importance of understanding the economy and its functions with society in mind. Talcott Parsons in his introduction of the 1947 translation of Weber's seminal work "Economy and Society" rightly highlighted that Weber himself "emphatically" stressed that his work is not in any sense "economic theory" (Weber 1964, p. 31). Parson articulately described Weber's work as "rather an account of the social....structure of systems of economic activity” (Weber 1964, p. 31).

Therefore, by taking a sociological approach to analysing and understanding the economy, Weber started in "Economy and Society" with defining some basic sociological concepts before later on arguing their relevance to the structure of the economy 
(Swedberg 2000). ${ }^{14}$ Hence, a central theme to Weber's argument was the link between the economic sphere and the social sphere with a particular reference to the influence of some of the latter's organisations, such as religion, on the former (Barber 1995; Swedberg 2000). Accordingly, this has an implication on the relationship between law and economy. Law is not a means devised to guarantee only economic interests as envisaged under the "law and economics" paradigm. Rather, law is also a means to protect a diverse range of social interests including positions of social pre-eminence which may be "economically conditioned or economically relevant in the most diverse ways, but which are neither economic in themselves not sought for predominantly economic ends" (Weber 1978, vol.1, p. 333).

Karl Polanyi's work also argued in favour of analysing and understanding the economy through the lens of society. In his seminal work "The Great Transformation," Polanyi introduced the concept of "embeddedness" which challenged the dominant conception of the relationship between economy and society. Polanyi's concept of "embeddedness" defies the notion that the economy is autonomous and society and social relations are subordinated to the economy (Polanyi 2001, pp. xxiii-xxiv). He argued that such conception would create an economic system only controlled by the market and its self-regulating mechanisms. This means "no less than the running of society as an adjunct to the market. Instead of economy being embedded in social relations, social relations are embedded in the economic system" (Polanyi 2001, p. 60). Accordingly, the danger of society being subordinated to the economy is that the livelihood of individuals is only secured by economic institutions. This creates a system that lacks "a conscious intervention of human authority, state or government" (Polanyi 1977, p. 47), and in which the only legal necessity is the protection of property and enforcement of contracts (Polanyi 1977, pp. 47-48). In order to counter this danger, Polanyi argued in "The Great Transformation" that the economy should be embedded in social relations and society, where the economy and society should not be considered two separate entities. Since then, the concept of "embeddedness" has found its way into the historical and political writing on the notion of moral economy (Granovetter 1985, p. 482). Further, a considerable body of literature has developed examining the meaning of "embeddedness," its application and the forms in which it can be achieved (for instance, Block 2003; Cotterrell 2013; Dale 2010; Granovetter 1985; Perry-Kessaris 2011).

It can be suggested that the collective work of Polanyi took a diverse approach to explaining the concept of the "embeddedness" of the economy.

On the one hand, in "The Livelihood of Man," Polanyi provided an anthropological perspective on the issue in order to prove that an embedded economy is not an alien concept. He demonstrated that being embedded in social relations was, in tribal societies, the natural status of any economic system and that from which economic institutions later evolved (Polanyi 1977). This significant social dimension of an embedded economy, according to Polanyi, sheltered economic interactions from "the corrosive effects of antagonistic emotions" (Polanyi 1977, p. 56) associated with economic motives such as profit, gain and payment (Polanyi 1977, p. 52). However, in order to optimise the identified advantages of an embedded

\footnotetext{
${ }^{14}$ For instance Weber discussed the sociological concepts of "communal relationship" and "associative relationship" where the first one entails a form of belonging and the second purely based on interest, he argued that most economic actions have a communal aspect to them which is rather important. See Swedberg, R. (2000). Max Weber and the idea of economic sociology. Princeton: Princeton University Press.
} 
economy, there is a need for "an elaborate social organisation" that can perform this task, which was fulfilled in tribal societies by "kinship" (Polanyi 1977, p. 53, 55).

On the other hand, in "The Great Transformation," Polanyi examined the need for the concept of "embeddedness," its applicability and the social organisations necessary for an optimised embedded economy. In this regard, his argument was highly attentive to the social and economic changes brought by the Industrial Revolution towards the end of the eighteenth century and the early nineteenth century. "The Great Transformation" depicted a clear picture of the changes to the economic sphere in which a self-regulating market, supported by the political powers at the time, became the organising power of the economy. Consequently, the evolution of "market economy" was a landmark shift that had far-reaching effects, which went beyond the economic sphere into the social fabric of the society.

Polanyi argued that the new economic order commodified all elements of industry, namely labour, land and money, which did not have the features of true commodities. Neither one of these three elements was produced for sale. While money is a "token of purchasing power" (Polanyi 2001, p. 75), labour and land, respectively, are "no other than the human beings themselves of which every society consists and the natural surroundings in which it exists" (Polanyi 2001, p. 75). Subsequently, the creation of these "fictitious commodities" (land, labour and money) subjected them to the market's supply-and-demand and price mechanisms, which are known as the "market laws." This was found by Polanyi to have socially damaging effects since a self-regulating market, governed only by the "market laws," first, subordinated the substance of society, that is labour and land, to the economy through turning them into "fictitious commodities" traded on the market (Polanyi 2001, p. 75). Second, it inherently required the creation of separate economic institutions (i.e., disembedding the economy from the society), which were driven by a distinctive economic motive namely gain and profit (Polanyi 2001, p. 74). Therefore, Polanyi warned of the "demolition of society" if "human beings" (labour), "natural environment" (land) and "purchasing power" (money) were to be solely directed by the market laws (Polanyi 2001, p. 76).

Although Polanyi's use of the term "demolition of society" could be described as an exaggeration, this is not to stay that the creation of these fictitious commodities, in particular land and money, and subjecting them merely to the market laws have not had any adverse effects on the well-being of societies. Take for example the 2008 global financial crisis and more specifically the collapse of Northern Rock. It has been argued that the bank's risky mortgage lending policy was part of a wider market practice in which providers needed to respond to a sharp increase in demand in the property market. This demand was not always created out of necessity, rather it was largely driven by the commodification of real properties with the number of buy-to-let mortgages soaring in the run up to the 2008 financial crash (Aldohni 2011).

Another, and more relevant, example is the commodification of money and its role in fuelling the 2008 financial crash. For Polanyi, changing the nature of money from a "token of purchasing power" to a product for sale ought to have a damaging effect on societies. This is a standpoint that has proved its accuracy particularly in the last few years. For instance, the 2008 financial crisis that brought austerity and financial hardship to a large segment of the society was fuelled by the use of debt as a tradeable commodity in complicated financial products. Further, since 2008, banks have become more stringent with their lending policies, which created a gap in the credit market that has been since filled by HCSTC providers. The proliferation of HCSTC providers is a by-product of the 2008 financial crash who since have gained a significant presence online and on high 
streets. Data collected by the Bureau of Investigative Journalism in March 2014 showed that there were 1427 HCSTC lender shops in England, Scotland and Wales with high concentration in impoverished areas (Bureau of Investigative Journalism 2014). Those lenders have clearly benefited from the commodification of money and have significantly profited from subjecting their "fictitious" product to the market laws only. This has allowed them, up until January 2015, to charge an extortionate interest rate without any regulatory objection considering that this was the market price of their product, which the market produced through the mechanism of supply and demand.

The main problem with subjecting the price of HCSTC only to the supply and demand mechanism is that it fails to take into any consideration the social context of the HCSTC market. As demonstrated earlier in this article, throughout the history, consumers of HCSTC have always been the most vulnerable in society with a weak bargaining position. It was estimated that the average HCSTC customer has a lower income level than the UK population as a whole - the average annual income in the UK is $£ 26500$ (Office of National Statics figures cited in Maguire 2014), for instance, 32\% earn less than $£ 12000$ per annum and 60\% earn less than $£ 18000$ per annum (FCA November 2014).

This outcome would not have been accepted by the regulator had it not adopted a regulatory approach that was primarily influenced by the "law and economics" theoretical frame.

It is, therefore, argued that the solution to this problem lies with having an embedded HCSTC market. This means a credit market in which the society can benefit from the presumed state authority, through the introduction of socially concerned regulations that control individuals' greed and limit their pursuit of gain (Watson 2005; Dale 2010). Accordingly, the criteria of such market primarily include, first, regulatory appreciation of the societal dimension of the HCSTC market. Second, and more importantly, a state role that goes beyond only protecting economic interests to include a diverse range of social interests. In other words, all markets require ground rules; however, what makes a market embedded is the focus of these rules. In an embedded HCSTC market, rules ensure that money as a fictitious commodity is not only governed by the market forces but also governed by societal needs, and that private property rights are protected without undermining the wider social interests.

In this regard, the rest of the discussion in this Part will collectively make two main arguments. First, it will be suggested that the recent changes introduced by the Financial Conduct Authority (FCA) to the HCSTC regulatory framework signify a departure from some of the fundamental premises of the "law and economics" theoretical frame. It is the type of change that Peter Hall describes as a "third order change" (Hall 1993, p. 279). According to Hall (1993), this type of change is always associated with radical changes to the continuous patterns of the policy in question. In the context of HCSTC, the introduction of a number of regulatory protective measures and capping the cost of credit by the FCA are a discontinuation of the main pattern of the "law and economics" paradigm namely self-regulation and market laws. While discussing the characteristics of a "third order change," Hall explains that such a change "is likely to be more sociological than scientific," in other words, "more political in tune" (Hall 1993, pp. 280, 288). As expert opinions may conflict, politicians will have to decide to which they should attach the greatest authority (Hall 1993). This can be seen in the process that led to the Government's decision to make its radical shift in its regulatory approach to the HCSTC market. There are a number of examples that demonstrate this shift. For instance, the original stance of the Government was that capping the cost was not needed and, moreover, was not desirable. However, with a growing political and media pressure, the Government made 
its U-turn (BBC 2013; Watt and Wintour 2012). In Hall's words, "policy changed, not as a result of autonomous action by the state, but in response to an evolving societal debate that soon became bound up with electoral competition" (Hall 1993, p. 288).

Second, it will also be argued that this "third order change" maps onto a Polanyian based "law and society" theoretical framework in which the concept of embeddedness has a central role to play.

\section{A "Third Order Change" to the Regulatory Approach to HCSTC Market}

It has been suggested that Polanyi's concept of embeddedness encompasses the political and social goal of ensuring that fictitious commodities are regulated in order to secure a stable democratic society (Beckert 2009; Dale 2010). In part, this can be achieved through the process of shaping economic behaviour by law making governmental interventions (Block 2003; Watson 2005). In other words, taking legal and regulatory steps that go beyond only facilitating economic functions within the market.

It can be argued, therefore, that since the FCA has taken over as the regulator of consumer credit, in April 2014, a host of measures were implemented to affect this shift.

First, in July 2014, the FCA capped the debt roll overs to two times to protect HCSTC from falling into a debt spiral (FCA 2014c). It is the type of intervention that is not primarily concerned with the functioning of the market rather with its social backdrop. As argued earlier in Part I, vulnerability has always been a feature of high-cost credit consumers and more specifically HCSTC consumers. Therefore, this regulatory intervention is an important step to embed the HCSTC market, as it is concerned with the protection of the social aspect of the market for a change.

Second, the OFT report found that the majority of HCSTC providers failed to properly comply with the requirement to carry out a rigorous affordability and creditworthiness assessment (OFT 2013). Therefore, in order to ensure the enforceability of this requirement, the FCA made it part of its binding rules in the FCA's Handbook. CONC 5.2.1R (1) states that the firm must undertake the creditworthiness assessment before entering into a credit agreement. More importantly, the HCSTC providers are required by the FCA rules to consider the adverse impact that the agreement will have on the customer's financial position (CONC 5.2.1R (2-a)). Further, the FCA also introduced other rules to safeguard the effectiveness of the creditworthiness assessment. On the one hand, HCSTC providers "must establish and implement clear and effective policies and procedures to make reasonable creditworthiness assessment" (CONC 5.3.2R). On the other hand, it is the HCSTC provider's duty to ensure the truthfulness of the information provided by the customer for the purpose of the creditworthiness/affordability assessment. The firm will be in breach of this rule if the firm "knows or ought reasonably to suspect that the customer has not been truthful" (CONC 5.3.7R).

Finally, the price cap introduced by the FCA is a significant shift from the "law and economics" theoretical framework and a step closer towards embedding the HCSTC market in society. This is because, as identified earlier, one of the criteria of an embedded HCSTC market is a state involvement that understands the importance of protecting the economic interests in the market; yet, it is designed to protect the wider societal interests beyond the market.

The FCA has introduced a three layers cap, which came into effect on the 2nd January 2015 and is designed to deal with three main sources of concern in the HCSTC market, namely, 
interest, fees and default charges (FCA 2014a). The first layer, the initial price cap, covers interest rates and fees as HCSTC providers cannot now charge more in interest and fees than $0.8 \%$ per day of the amount borrowed (FCA 2014a). The second layer targets default charges as it restricts the amount paid in default to a total of $£ 15$ whether the debt is being repaid in instalments or in a single payment. This means that HCSTC providers cannot charge $£ 15$ for each instance of default when borrowers are paying back by instalments, and in any case, the cumulative total default charges should not exceed $£ 15$ (FCA 2014a). The third layer is a total cost cap where a borrower should never pay more in interest, fees and charges than $100 \%$ of the amount borrowed.

Leading from that, there are a number of observations that can be made with regard to the FCA's price cap and its link to the highlighted criteria of an embedded HCSTC.

First, in setting up the price cap, the FCA has shown a genuine concern about the noneconomic well-being of the borrowers, demonstrating that there is a larger social goal to the policy. Throughout the price cap implementation document, the FCA emphasised that although losing access to HCSTC as a result of the price cap would have both negative and positive effects, the latter would outweigh the former. In making its case, the FCA not only relied upon economic analysis, which showed that, in the past, using HCSTC worsened the financial position of those borrowers who would lose their access to this type of credit after imposing the price cap, the FCA also referred to other positive welfare consequences for borrowers that the loss of access to HCSTC would cause, such as the reduction of stress, psychological and mental problems associated with over indebtedness (FCA 2014a).

Second, it is clear that the FCA's price cap represents a governmental intervention aiming at shaping the financial behaviour of HCSTC providers in a way that achieves a more stable society. In particular, imposing the first layer of the price cap, the initial cost cap, deprives HCSTC lenders of the financial benefits of lending to those who will not be able to pay back their debt. For long time, HCSTC providers pursued a strategy to lend borrowers who are incapable of paying back their debt so they can roll over the debt as many times as possible continuing to charge an extortionate interest rate and fees before eventually charging extortionate default charges. However, they can only roll over the debt for two times and the maximum rate that they can now charge in interest and fees is limited to $0.8 \%$ per day. By setting up the rate at $0.8 \%$, the FCA aims to "change the underlying commercial incentives to lend to the riskiest borrowers" (FCA 2014a, p. 34).

However, it must be noted that Polanyi's embeddedness concept does not advocate an unrestrained form of governmental interventions. This can be clearly seen in Polanyi's sharp criticism of a particular regulation, Speenhamland law, which primarily concerned one of the fictitious commodities, namely labour. Speenhamland law concerned the well-being of labour during a period of financial hardship. It created an allowance system for labour, mainly in the countryside, which meant that a relief or subsidy was paid in aid of certain low wages in accordance to an adopted scale in which the price of bread was the benchmark. This law had backfired as it dis-incentivised labourers to satisfy their employer since they were guaranteed a particular income whatever wages they earn. Consequently, labourers' productivity plummeted and employers found an excuse to keep wages at low levels (Polanyi 2001).

In this regard, it can be suggested that the FCA was careful of the difficult balance that embedding HCSTC market requires. The FCA's price cap can be described as a measured intervention that is not supposed to undermine the HCSTC market in the long run by disproportionally favouring borrowers. This is a point that the FCA highlighted regularly in 
its price cap implementation document especially in the context of default charges. Although many respondents to the original consultation on the price cap (FCA 2014b) criticised the proposed fixed $£ 15$ cumulative default charges for being an inflated and an unreasonable estimate of the true cost of default, the FCA maintained its cap on default charges at $£ 15$ (FCA 2014a). Further, the FCA has not, at least for now, requested HCSTC lenders to freeze interest charged in default subject to the $0.8 \%$ cap per day. It is important to note that this was balanced out by a rule included in the FCA's Consumer Credit Sourcebook, Chapter 7 (CONC 7.3.4R), which requires lenders to "treat customers in default or in arrears difficulties with forbearance and due consideration" (FCA 2014a).

It is clear that the FCA is not taking a powerful paternalistic approach with regard to its price cap in general and default charges more specifically. For instance, defaulting on a loan of $£ 150$ means that borrowers can end up paying up to $10 \%$ of the total amount in default charges alone, which is still considerably high bearing in mind the social backdrop of this type of credit. However, this is necessary to incentivise borrowers to pay their debt on time. Diminishing default charges in the case of HCSTC would not only have economic adverse effects on lenders but would also reduce the sense of responsibility of borrowers.

It is worth noting that at the time of writing this article, the FCA is reviewing the price cap to assess if there is evidence-based reason to change the price cap. The FCA also aims to find out whether the cap has led to an increase in the use of illegal lending by those who were excluded from the use of HCSTC as a result of the price cap (FCA 2016b, c).

\section{Towards a More Embedded High-Cost Short-Term Credit Market}

Given that it is essential to the embeddedness of the HCSTC market to take into account the societal dimension of this market, this section argues that there are a number of ways in which this could be achieved, including utilising the other social institutions in this market and promoting the presence of social credit.

\section{The Utilisation of Other Social Institutions}

As argued earlier, the price cap and the other regulatory interventions represent an essential part of the required infrastructure of embeddedness in the context of HCSTC. However, there are other social institutions that can be utilised to complement this infrastructure. One of these key social institutions is the knowledge and information institution (Barber 1995). The borrowers' level of knowledge and understanding of information plays a significant role in the process of valuation, which is largely social in character (Beckert 2009) and essential to their decision making.

It must be noted that this is quite different from information transparency advocated by the "law and economics" theoretical framework and long adopted by the regulator in the UK (DTI 2003). Transparency and disclosure measures in the context of HCSTC presume that borrowers are empowered if they are told, for example, the interest rate and amount of money they are or will be paying in interest. However, these measures have proved ineffective in protecting HCSTC consumers because being told that you will pay an extortionate interest rate does not protect you from becoming over indebted, whether the borrowing is driven by a life necessity or by only conspicuous consumption. Therefore, sole reliance upon these measures has been finally rejected by the FCA (FCA 2013). 
The FCA touched on the issue of consumer knowledge and education in its CP13/10 "Detailed Proposal for the FCA Regime for Consumer Credit." While highlighting some of the proposed rules for HCSTC, the FCA referred to some "consumer education measures" (FCA 2013, p. 75). In this context, the FCA stated that these measures "will empower consumers at key decision points with information that could lead to them taking decisions that lead to better outcomes" (FCA 2013, p. 75). In principle, "consumer education" in the context of HCSTC is a wide-ranging concept that encompasses a selection of powerful tools, which help shape economic behaviour from a consumer's perspective. Among which there are enhancing consumer's financial literacy and also providing better information provisions as both significantly improve the valuation process upon which consumers make their decisions. This section will not examine the role of financial literacy rather it brings focus to information provisions highlighting where the regulator is failing to utilise this means, which could be particularly useful to protect the new client base (those who are young, financially naive and driven by consumerism) of online HCSTC providers.

In its CP13/10 "Detailed Proposal for the FCA Regime for Consumer Credit," the FCA prioritised some specific provisions of information namely, debt warning and information on debt advice. It proposed that HCSTC providers should include a debt warning in any electronic communications (websites...etc.) and in their adverts. It also proposed that they need to provide information on free debt advice before the point of roll over. While in principle, these proposals are essential to further improve the valuation process of consumers, there are some critical observations that can be made in this respect.

One the one hand, in the initial consultation document in October 2013, the FCA proposed the following warning:

"Think! Is this loan right for you? Over 2 million short-term loans were not paid off on time in 2011/2012. This can lead to serious money problems. If you're struggling, go to www.moneyadviceservice.org.uk for free and impartial help." (FCA 2013, p. 69).

The warning in its proposed form was designed to specifically address HCSTC and capture the attention of its online borrowers. The aim of the proposed warning to get potential borrowers to question their actual need to use this type of credit. It then provides a loss framed warning as it presents specific evidence on the danger of using HCSTC. Finally, it points them towards a source - the Money Advice Service - where they can discover other funding alternatives to HCSTC.

Unfortunately, the warning was not implemented in the same terms as the FCA's initial proposal. In particular, the implemented warning does not have the first two salient features of the proposed warning. It simply states

"Warning: Late repayment can cause you serious money problems. For help, go to moneyadviceservice.org.uk" (FCA 2014c, p. 55).

Accordingly, it would not trigger consumers to question their need to use this type of credit, a point that could have a significant effect on online borrowers with consumeristic motives.

Moreover, instead of highlighting some hard evidence on the risks of using HCSTC, it provides no more than a generic statement that can apply to all types of credit.

This is particularly dangerous for a number of reasons. First, using this general term "late payment" would not necessary make consumers think about this danger in the context of HCSTC considering that their judgement can be clouded by self-serving interpretation and a sense of false optimism on their ability to make payments (Howells 2005). 
Second, and more importantly, the warning no longer has a loss framed format, which research showed is an effective way to capture consumers' attention and get them to think about the risks associated with their actions. ${ }^{15}$

In other words, although both statements, one way or another, deliver the same message, using loss framed format, such as including some facts about the rate of default in HCSTC or even the damages associated with it, would improve the cognitive responses of consumers.

Finally, the FCA failed to look into how the warning should be displayed by the HCSTC providers. This is a rather critical issue as it influences the effects that any warning might have. The extensive research that has been done in relation to warnings on cigarette packs proved the significance of this issue. The key finding of the collective research on the display of cigarette packet warnings is the superior impact that graphic and large text warnings have with regard to better communicating smoking risks, convincing smokers of the reality of these risks and, arguably, leading to cessation behaviour (Borland et al. 2009; Emery et al. 2014; Travers et al. 2011). While the use of graphic warning is less possible in the context of HCSTC, the FCA should pay a particular attention to how prominently and how often HCSTC lenders display their text warning. By looking at a number of online lenders' websites, one can easily see how the lack of attention to this issue has already been exploited by some of the HCSTC lenders. For example, Wonga, Satsuma and Quick Quid do not have the warning displayed in bold. ${ }^{16}$ Further, Wonga and Satsuma use a small size text for the warning and it is displayed on a coloured background that makes it hardly visible. ${ }^{17}$

On the other hand, it can be suggested that there are other information provisions, than debt warning and information on debt advice, which should be considered to empower consumers' decision making abilities. This is something that the FCA alluded to in CP13/10 "Detailed Proposal for the FCA Regime for Consumer Credit" but does not seem to have followed through so far. In its October 2013 consultation, the FCA referred to the need to conduct more behavioural research into ways to "nudge" consumers to make better choices (FCA 2013, p. 78). The concept of a "nudge" was developed by Thaler and Sunstein (2008) in their seminal book "Nudge: Improving Decisions about Health, Wealth and Happiness." They define a nudge as "any aspect of the choice architecture that alters people's behaviour in a predictable way without forbidding any options or significantly changing their economic incentives. To count as a mere nudge, the intervention must be easy and cheap to avoid" (Thaler and Sunstein 2008, p. 6). Accordingly, it can be argued that information provisions can be developed to work as an effective nudge. For instance, information can be framed in a way that reminds borrowers of the cost of their current borrowing in the form of future spending that must be forgone in order to pay their debt highlighting the significant trade-off. Also, when borrowing small amounts, information can be used to minimise the "peanuts effect" where borrowers do not fully consider

\footnotetext{
${ }^{15}$ This research was conducted regarding warnings and labels on cigarette packs see Bansal Travers, M., Hammond, D., \& Cummings, K. M. (2011). The Impact of Cigarette Pack Design, Descriptors and Warning Labels on Risk Perception in the U.S. American Journal of Preventive Medicine, 40(6) 674-682.

${ }^{16}$ Quick Quid, https://www.quickquid.co.uk/ accessed 22.03.16, Wonga, www.wonga.com accessed 22.03.16, Satsuma, https://www.satsumaloans.co.uk/?ref=GO_AT\&st=satsuma\&kwcid=1\&cmpid=paid_search-googlebrand_core_p-brand_core_p_core-satsumas\&s_kwcid=AL!535!3!79250954943!p!!g!!satsuma\&gclid=COHh39 y-3ccCFSMewwod3-MGVQ\&ef_id=Us5r-wAAAemLvJsQ:20150904133142:s

${ }^{17}$ Accessed 22.03.16.

Wonga www.wonga.com Satsuma, https://www.satsumaloans.co.uk/?ref=GO_AT\&st=satsuma\&kwcid=1 \&cmpid=paid_search-google-brand_core p-brand_core p_core-satsumas\&s kwcid=AL!535!3!79250954943 !p!!g!!satsuma\&gclid=COHh39y-3ccCFSMewwod3-MGVQ\&ef_id=Us5r-wAAAemLvJsQ:20150904133142:s Accessed 22.03.16.
} 
the results of small amount transactions (Bertrand and Morse 2011, p. 1873). This requires showing borrowers the total amount that they would end up paying, including interest, fees and charges, if they used the maximum two rollovers allowed by the FCA (FCA 2014b).

Further, information can be used to suggest a starting point for the thought or valuation process of borrowers, which is known as "anchoring" (Thaler and Sunstein 2008, p. 26). This means that when borrowers are applying for HCSTC, they should be asked to fill in the previous amounts of HCSTC that they borrowed and the actual amounts they paid back. This would subtly make these experiences the starting point of borrowers' valuation process and an integral part of their constructed narrative, which is the basis of their credit decision. Despite suggestions that as part of the "planning fallacy" problem, individuals tend to discount past negative experiences (Buehler et al. 1997), it can be argued that reminding borrowers of past experiences with a clear causal link with the present would make it difficult for them to automatically discount the negative past. Research has found that the tendency to neglect evidence contradicting the preferred answer, which in the case of borrowing is to say yes, can be mitigated by making the evidence more salient (Koriat et al. 1980).

The positive effects of these suggestions may not be conclusive; however, their valid underlying principles make them worth investigating more seriously in the context of HCSTC.

\section{The Promotion of Social Credit Sources}

It is important to note that the term "social credit" in this context refers to affordable credit that is originated in the community or made available through the state welfare system, and it is argued here that it is an essential means to protect those who are in desperate need of credit.

The lack of affordable alternatives that HCSTC consumers can resort to (i.e., "supply vulnerability") seems to be a neglected aspect of the HCSTC problem (Aldohni 2013). It is suggested here that addressing this aspect is essential to embed the HCSTC market in the society. Social credit sources, in this respect, are essential as they complement the protective regulatory measures taken since the FCA became the regualtor in 2014, more specifically the credit cost cap. The HCSTC industry argued that controlling the cost of credit would drive the credit providers out of the market and force consumers to use "more expensive, less desirable and possibly unregulated alternatives" (Consumer Finance Association 2013; University of Bristol, Personal Finance Research Centre 2013, p. 117-118). Social credit sources, accordingly, play a vital role in mitigating this side effect provided it materialised. ${ }^{18}$ Therefore, it is essential to facilitate the creation or the promotion of socially based credit sources. Unfortunately, the UK has, arguably, not made a steady progress in this respect for the reasons demonstrated below.

On the one hand, under the New Labour Government, the Department of Work and Pension (DWP) was allocated a Growth Fund. The DWP Growth Fund was set up as a part of the Government's financial inclusion agenda (Mckillop et al. 2011). The primary aim of this fund was to develop the capacity of third sector lenders, such as credit unions and Community Development Finance Institutions (CDFIs), to serve deprived and excluded borrowers by providing access to affordable credit (typically between 12 and 28\% APR) and help those lenders with the cost of lending (Collard et al. 2010). Despite its success in extending credit to financially excluded individuals in deprived communities and expanding the personal lending operations of credit

${ }_{18}$ Although the Bristol University report (March 2013) was not in favour of price restrictions it suggested that they can be imposed if other credit alternatives were available, p. 117-118. 
unions and CDFIs (Collard et al. 2010), the DWP Growth Fund ended in March 2011 as a part of the austerity measures post 2010. With the absence of this funding, borrowers on low incomes would be forced to use more expensive credit and resort to HCSTC providers.

In response, the Coalition Government found credit unions as "the only other realistic option" to serve low-income consumers (DWP 2012, p. 4). However, the current organisational and business structure was found to be an obstacle and would need to be modernised in order for them to stand as a sustainable, credible and effective source of finance to individuals on low income. Therefore, the Government took a number of steps in this respect.

First, the DWP launched in May 2012 the "DWP Credit Union Expansion Project" the feasibility study of which examined "the sustainability of credit unions" and "what more can be done to expand them to serve many more people on lower incomes" (DWP's announcement in the House of Commons, cited in Edmonds 2015, p. 30). In April 2013, the Government awarded the Association of British Credit Unions Ltd. (ABCUL) the contract (worth $£ 38$ million) to deliver DWP's Credit Union Expansion Project in order to modernise and grow credit unions (DWP 2016). The project was planned to end in April 2016; however, a request has been made for a further extension which is, at the time of writing this article, under Government consideration (UK Parliament 2015). Given that the modernisation project is not yet complete, it is difficult to assess its effectiveness. Nonetheless, it is fair to suggest that by investing in credit unions, the government has taken an important step to promote the infrastructure for embeddedness. This is due to the nature of credit unions as they are "strongly embedded in their local communities and are committed to assisting those on low incomes" and "often appeal to low income consumers as bodies which are local, accessible and convenient and which are community based" (Sajid Javid, the then Economic Secretary to the Treasury cited in Edmonds 2015, p. 34).

Second, as of 1st April 2014, the government introduced a statutory change to section 11 (5) of the Credit Union Act 1979 that allowed credit unions to charge interest up to 3\% per month-i.e., 42.6\% APR (The Financial Services and Markets Act 2000 (Regulated Activities) (Amendment) (No.2) Order 2013(Art.06)); HM Treasury 2013, p. 12). This 1\% increase was specifically brought to ensure that credit unions do not make a loss when they lend shortterm small loans (up to $£ 1000$ ) which improves their ability to provide this type of credit and compete with HCSTC lenders (HM Treasury 2012).

On the other hand, Social Funds, which the New Labour Government primarily made available to people living on a low income with much needed lump sum payments and interest free loans (Kempson et al. 2002), were abolished from April 2013. This meant that crisis loans, which were also available to even those who were not on qualifying benefits, no longer exist. Local authorities were asked to devise their own schemes to provide emergency assistance (Rahilly 2011).

The government still offers budgeting loans where individuals on qualifying benefits can use them to obtain interest-free loan to pay for essential things (furniture, clothes, moving costs or hire purchase debts) with loan repayments being deducted directly from their benefits. ${ }^{19}$

It has been argued that Social Funds never had the capacity to deal with the increasing demands (Collard 2007). However, instead of abolishing them, the Government should have looked into new ways through which Social Funds capacity could have been improved. In this regard, it has been suggested that Social Funds should be allowed to have initial interest-free

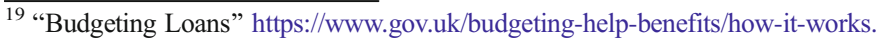


credit limit after which they can charge affordable interest rates (Collard and Kempson 2005). This means an interest rate which is in line with the offering of other social lending facilities.

Additionally, devolving the system of emergency fund (crisis loans) to local authorities does not really deal with the capacity problem. Rather, it shifts the problem to a less financially able authority given the financial cuts faced by local councils and provides the residents of poorer cities with less emergency financial assistance.

\section{Conclusion}

There is no doubt that the business model of high-cost credit, more specifically HCSTC, has evolved over the years. However, as demonstrated in part I, the vulnerability of its consumers has remained a defining feature of the HCSTC market. Further, the new online platform of the HCSTC business has widened the social groups that are exposed to the risks associated with this type of credit.

Up until 2014, the regulator, under different consecutive UK governments, had failed to take meaningful measures to protect the ever increasing numbers of HCSTC consumers. This was not due to regulatory incompetence but rather due to a regulatory ideology that prioritised the market over its bedrock that is society. The regulation that was in place only facilitated the functioning of the market and enforced its laws namely supply and demand and pricing. For instance, although the OFT, the former regulator, published irresponsible lending guidance, it was effectively enforced.

Further, the court in applying the "unfair relationship test" paid particular attention to the practice of the market regarding the interest rate. This is not to say that the court failed to establish the link between unfairness and high interest rate. As demonstrated in Pelvin (2014), the Supreme Court made the vulnerability of the consumers (discussed earlier in Part I) and the availability of other credit options as important considerations in deciding on the fairness of the credit agreement.

On the other hand, the recent implementation of a number of regulatory measures by the FCA - capping the number of roll overs, enforcing the requirement of creditworthiness/ affordability assessment and capping the HCSTC price - has signified a departure from the law and economics model of regulation towards a more socially anchored one, in which the concept of "embeddedness" has a central role.

As argued earlier, "embeddedness" in this context encompasses the use of social organisations in shaping economic behaviour and the implementation of socially concerned regulation that goes beyond the interest of the market. Where a threshold level of embeddedness is maintained in the market (Block 2003), the society can benefit from the presumed state authority, through the introduction of socially concerned regulations that control individuals' greed and limit their pursuit of gain (Watson 2005).

This is what these regulatory measures, in principle, are set to achieve. They are designed to keep a viable business model for the HCSTC providers without jeopardising the protection of the borrowers. It is also clear that the regulator is committed to ensuring the effectiveness of these measures. At the time of writing this article, the FCA is reviewing one of its important measures, namely HCSTC price cap, in order to assess whether there is a need to change this measure.

Further, the infrastructure of embeddedness in the context of HCSTC would require the use of other social institutions such as knowledge and education. In this respect, the FCA has taken certain steps since July 2014 to utilise the use of the information provisions to protect HCSTC 
consumers. In this regard, the FCA imposed the requirements for debt warnings and debt advice to be displaced by the HCSTC providers.

However, the implementation format of these measures especially in relation to debt warnings fell short. This significantly undermines their effectiveness in communicating the risks associated with this type of credit. Therefore, the FCA should review how currently the debt warning requirement is being implemented by HCSTC providers. This is essential to ensure that the warning achieves its optimal effect and to prevent HCSTC providers from undermining the benefit of this information provision. The FCA has yet to explore other information provisions that empower borrowers to make a better valuation before taking on HCSTC. This is an area that is supported by a large volume of behavioural literature; yet, it still needs to be utilised by the FCA in the context of HCSTC.

Finally, the promotion of "social credit sources" was found to be an essential of part of the embeddedness process for HCSTC market. In this regard, the Government efforts to modernisation and expansion of credit unions are a welcome step. Credit unions, as socially embedded institutions, would help address the issue of credit supply vulnerability in their communities. On the other hand, the cuts to the welfare state have not helped the promotion of "social credit sources." The abolition of Social Funds, in particular "crisis loans," is a setback to the quest of promoting affordable credit to the most vulnerable. The government should have looked into ways to make Social Funds less expensive for the government and more sustainable instead of abolishing them and shifting this problem to local councils, especially in poor cities, which are already faced with significant budget cuts.

Open Access This article is distributed under the terms of the Creative Commons Attribution 4.0 International License (http:/creativecommons.org/licenses/by/4.0/), which permits unrestricted use, distribution, and reproduction in any medium, provided you give appropriate credit to the original author(s) and the source, provide a link to the Creative Commons license, and indicate if changes were made.

\section{References}

Aldohni, A. K. (2011). The bank that rocked: Does the problem lie in the global business model of conventional banking? In J. Gray \& O. Akseli (Eds.), Financial regulation in crisis?: The role of law and the failure of Northern rocked (pp. 88-106). Cheltenham: Edward Elgar.

Aldohni, A. K. (2013). Loan sharks v. Short-term lenders: How do the law and regulators draw the line? Journal of Law and Society, 40(3), 420-449.

Barber, B. (1995). All economics are embedded: The career of a concept and beyond. Social Research, 64(2), $387-413$.

BBC. (2013). Payday loans: New law to cap costs. Available at http://www.bbc.co.uk/news/uk-politics25083701.

BBC. (2014). Worrying' number of undergraduates use payday loans. Available at http://www.bbc.co. uk/news/education-27811593.

Beckert, J. (2009). The great transformation of embeddedness: Karl Polanyi and the new economic sociology. In C. Hann \& K. Hart (Eds.), Market and society: The great transformation today (pp. 38-55). Cambridge: Cambridge University Press.

Bertrand, M., \& Morse, A. (2011). Information, cognitive biases and payday borrowing. The Journal of Finance, 66(6), 1865-1893.

Block, F. (2003). Karl Polanyi and the writing of "the great transformation". Theory and Society, 32(3), $275-306$.

Borland, R., Wilson, N., Fong, G. T., Hammond, D., Cummings, K. M., Yong, H.-H., et al. (2009). The impact of graphic and texts warning on cigarette packs: Finding from four countries over five years. Tobacco Control, $18(5), 358-364$.

Buehler, R., Griffin, D., \& Ross, M. (1997). Exploring the "planning fallacy": Why people underestimate their task compliant time. Journal of Personality and Social Psychology, 67(3), 366-381.

Bureau of Investigative Journalism. (2014). https://www.thebureauinvestigates.com/2014/03/12/uk-one-shortterm-lender-for-every-seven-banks-on-the-high-street/. 
Cayne, D., \& Trebilcock, M. J. (1973). Market considerations in the formulation of consumer protection policy. University of Toronto Law Journal, 23, 396-430.

Coase, R. H. (1959). The federal communications commission. Journal of Law and Economics, 2, 1-40.

Collard, S. (2007). Towards financial inclusion in the UK: Progress and challenges. Public Money \& Management, 27(1), 13-20.

Collard, S., \& Kempson, E. (2005). Affordable credit: The way forwards. Bristol: The Policy Press.

Collard, S., Hale, C. Day, L. (2010). Evaluation of the dwp growth fund: Revised final report. Available at http://www.bristol.ac.uk/media-library/sites/geography/migrated/documents/pfrc1101.pdf.

Consumer Finance Association. (2013). Industry briefing. Available at http://www.cfa-uk.co.uk/informationcentre/industry-briefings/current-briefings/should-uk-payday-loan-costs-be-capped.html.

Cotterrell, R. (2013). Rethinking “embeddedness”: Law, economy community. Journal of law Society, 40(1), 49-67.

Consumer Credit Act 1974. http://www.legislation.gov.uk/ukpga/1974/39/contents.

Dale, G. (2010). Karl Polanyi: The limits of the market. Cambridge: Polity Press.

Department for Work and Pension (DWP). (2016). Credit union $£ 38$ million expansion deal signed. London: DWP.

Department for Work and Pension (DWP). (2012). DWP Credit Union Expansion Project, Project Steering Committee, Feasibility Study Report. London: DWP. Available at http://webarchive.nationalarchives.gov. uk/20130102224139/http:/www.dwp.gov.uk/docs/credit-union-feasibility-study-report.pdf.

Department of Trade and Industry (DTI). (2003). Fair, clear and competitive: The consumer credit market in the $21^{\text {st }}$ century. White paper. London: DTI. Available at http://webarchive.nationalarchives.gov.uk/20070603164510 /http://www.dti.gov.uk/files/file23663.pdf.

Edmonds, T. (2015). House of commons library. Credit unions. Briefing paper number 01034. London: UK Parliament.

Emery, L. F., Romer, D., Sheerin, K. M., Jamieson, K. H., Peters, E. (2014). Affective and cognitive mediators of the impact of cigarette warning labels. Nicotine \& Tobacco Research, 16(3), 263-269.

Financial Conduct Authority (FCA). (2013). Detailed proposal for the FCA regime for consumer credit. Consultation paper 13/10. London: FCA. Available at http://www.fca.org.uk/your-fca/documents/consultation-papers/cp13-10.

Financial Conduct Authority (FCA). (2014a). Detailed rules for the price cap on high cost short term credit including feedback on CP14/10 and final rules. Policy statement 14/16. London: FCA. Available at http://www.fca.org.uk/your-fca/documents/policy-statements/ps14-16.

Financial Conduct Authority (FCA). (2014b). Proposals for a price cap on high-cost short-term credit. Consultation paper 14/10. London: FCA. Available at https:/www.fca.org.uk/static/documents/consultation-papers/cp14-10.pdf.

Financial Conduct Authority (FCA). (2014c). Detailed rules for the FCA regime for consumer credit including feedback on FCA QCP 13/18 and 'made rules. Policy statement 14/3. London: FCA. Available at https://www.fca.org.uk/static/documents/policy-statements/ps14-03.pdf.

Financial Conduct Authority (FCA). (2015). Consumer vulnerability. (February 2015) occasional paper no.8. London: FCA. Available at http://www.fca.org.uk/static/documents/occasional-papers/occasional-paper-8.pdf.

Financial Conduct Authority (FCA). (2016a). Thematic review: Early arrears management in unsecured lending. London: FCA.

Financial Conduct Authority (FCA). (2016b). Guide for consumer credit firms. London: FCA.

Financial Conduct Authority (FCA). (2016c). Call for input: High-cost credit including review of the high-cost short-term credit price cap. London: FCA.

Financial Conduct Authority (FCA). (2016d). FCA launches call for input on high-cost credit and overdrafts. London: FCA.

Finn, M. C. (2003). The character of credit: Personal debt in English culture, 1740-1914. Cambridge: Cambridge University Press.

Goff, S. (2012). Last traces of Northern Rock name vanish. Financial Times.

Golub, S. (2003). Beyond rule of law orthodoxy, the legal empowerment alternative. Vol. 41. Washington: Carnegie Endowment for International Peace.

Granovetter, M. (1985). Economic action and social structure: The problem of embeddedness. American Journal of Sociology, 91(3), 481-510.

Haldar, A. (2014). Law and development in crisis: An empirical challenge of the current theoretical frames. Northern Ireland Legal Quarterly, 65(3), 303-321.

Hall, P. (1993). Social learning and the state: The case of economic policymaking in Britain. Comparative Politics, 25(3), 275-296.

Harvey, D. (2005). A brief history of neoliberalism. Oxford: Oxford University Press.

Hayek, F. A. (1973). Law, legislation and liberty: Volume 1 rules and order. London: Routledge.

Hayek, F. A. (1978). The constitution of liberty. Chicago: Chicago University Press.

Hayek, F. A. (1988). The fatal conceit of: The errors of socialism. In W. W. Bartley III (Ed.), The collected works of F.A. Hayek, volume 1 (pp. 66-85). London: Routledge.

Hayek, F.A. (1994). The Road to Serfdom. Chicago: Chicago University Press. 
HM Treasury. (2012). Credit union maximum interest rate cap. London: HM Treasury. Available at https://www. gov.uk/government/uploads/system/uploads/attachment_data/file/221917/credit_union_maximum_interest_ rate cap181212.pdf.

HM Treasury. (2013). Raising the maximum interest rate cap: response to consultation. London: HM Treasury. https://www.gov.uk/government/uploads/system/uploads/attachment_data/file/206091/raising_the_ maximum_interest_rate_cap_response_to_consultation_110613.pdf.

Howells, G. (2005). The potential and limits of consumer empowerment by information. Journal of Law and Society, 32(3), 349-370.

Johnson, P. (1983). Credit and thrift and the working class, 1870-1939. In J. Winter (Ed.), The working class in modern British history: Essays in honour of Henry Pelling (pp. 147-170). Cambridge: Cambridge University Press.

Kamleitner, B., Hoelzl, E., \& Kirchler, E. (2012). Credit use: Psychological perspective on a multifaceted phenomenon. International Journal of Psychology, 47(1), 1-27.

Kempson, E., Collard, S., \& Taylor, S. (2002). Social fund use amongst older people. Department for Work and Pensions, research report no 172. London: DWP.

Koriat, A., Lichtenstein, S., \& Fischhoff, B. (1980). Reasons for confidence. Journal of Experimental Psychology: Human Learning and Memory, 6(2), 107-118.

Maguire, K. (2014). Where do you rank in the official earnings list? Figures reveal huge pay gap between rich and poor. The Mirror.

Mason, R. (1981). Conspicuous consumption: A study of exceptional consumer behaviour. Aldershot: Gower.

Mckillop, D., Ward, A. M., \& Wilson, J. O. S. (2011). Credit unions in great Britain: Recent trends and current prospects. Public Money \& Management, 31(1), 35-42.

Mudge, S. L. (2008). The state of the art: What is neo-liberalism. Socio-Economic Review, 6, 703-731.

O'Connell, S. (2009). Credit and Community: Working Class debt in the UK since 1880. Oxford: Oxford University Press.

O'Connell, S. \& Reid, C. (2005). Working-Class Consumer Credit in the UK, 1925-60: The Role of the Check Trader. Economic History Review 58(2), 378-405.

Office of Fair Trading (OFT). (2010a). Review of high cost credit: Final report. London: OFT. Available at http://webarchive.nationalarchives.gov.uk/20140402142426/http://www.oft.gov.uk/shared oft/reports/consumer_credit/High-cost-credit-review/OFT1232.pdf.

Office of Fair Trading (OFT). (2010b). Annexe B - Price controls: Evidence and arguments surrounding price control and interest rate caps for high-cost credit. London: OFT. Available at http://webarchive. nationalarchives.gov.uk/20140402142426/http://www.oft.gov.uk/shared_oft/reports/consumer_credit/Highcost-credit-review/OFT1232b.pdf.

Office of Fair Trading. (2012). A compliance review into payday lending. London: OFT Available at http://webarchive.nationalarchives.gov.uk/20131213013259/http:/oft.gov.uk/OFTwork/credit/paydaylenders-compliance-review/.

Office of Fair Trading (OFT). (2013). Payday lending compliance review: Final report. London: OFT. Available at http://webarchive.nationalarchives.gov.uk/20140402142426/http://www.oft.gov.uk/shared oft/Credit/oft1481.pdf.

Perry-Kessaris, A. (2011). Reading the story of law and embeddedness through a community lens: A polanyimeets- cotterrell economic sociology of law? Northern Ireland Legal Quarterly, 62(4), 401-413.

Polanyi, K. (1977). Edited by Harry W. Pearson. The livelihood of man. New York: Academic Press.

Polanyi, K. (2001). forwarded by J E. Stiglitz \& introduction by F. Block. The great transformation: The political and economic origins of our time. Boston: Beacon Press.

Quick Quid. (2016). https://www.quickquid.co.uk/.

R3: Association of Business Recovery Profession. (2013). Payday loan popularity dips - but demand amongst young adults 'worryingly high. Available at https://www.r3.org.uk/index.cfm?page=1114\&element=18969.

Rahilly, S. (2011). The end of the discretionary social funding. Journal of Social Security Law, 18(4), $147-149$.

Ramsay, I. (2010). To heap distress upon distress' comparative reflections on interest rate-ceilings. University of Toronto Law Journal, 60(2), 707-730.

Ramsay, I., \& Williams, T. (2009). The crash that launched a thousand fixes: Regulation of consumer credit after the lending revolution and the credit crunch. In: W G Hart legal workshop 2009: Law reform and financial markets: Institutions and governance, 23rd - 25th June 2009. London: Institute of Advanced Legal Studies Available at http://papers.ssrn.com/sol3/papers.cfm?abstract_id=1474036.

Crowther Report. (1971). Consumer credit: Report of the Committee. Cmnd 4596. London: The Stationary Office.

Richter, R. (2005). The new institutional economics: Its start, its meaning, its prospects. European Business Organisation Law Review, 6(2), 161-200. 
Satsuma. (2016). https://www.satsumaloans.co.uk/?ref=GO_AT\&st=satsuma\&kwcid=1\&cmpid=paid_searchgoogle-brand_core_p-brand_core_p_core-satsumas\&s_kwcid=AL!535!3!79250954943!p!!g!!satsuma\&gclid= COHh39y-3ccCFSMewwod3-MGVQ\&ef_id=Us5r-wAAAemLvJsQ:20150904133142:s.

Smith, A. (2008). An inquiry into the nature and causes of the wealth of nations. A selected edition. Oxford World's classics. Oxford: Oxford University Press.

Smith, N. C., \& Cooper-Martin, E. (1997). Ethics and target marketing: The role of product harm and consumer vulnerability. Journal of Marketing, 61(3), 1-20.

Swedberg, R. (2000). Max Weber and the idea of economic sociology. Princeton: Princeton University Press.

Swedberg, R. (2003). The case for an economic sociology of law. Theory and Society, 1, 1-37.

Taylor, A. (2002). Working Class Credit and Community Since 1918. Hampshire: Palgrave.

Tebbutt, M. (1983). Making ends meet, pawnbroking and working class credit. Leicester: Leicester University Press.

Thaler, R. H., \& Sunstein, C. R. (2008). Nudge, improving decisions about health, wealth and happiness. New York: Penguin Books.

Travers, M. B., Hammond, D., \& Cummings, K. M. (2011). The impact of cigarette pack design, descriptors and warning labels on risk perception in the U.S. American Journal of Preventive Medicine, 40(6), 674-682.

Trumbull, G. (2014). Consumer lending in France and America: Credit and welfare. Cambridge: Cambridge University Press.

UK Government. (2016). Budgeting Loans. Available at https:/www.gov.uk/budgeting-help-benefits/how-itworks.

UK Parliament. (2015). Credit Union: Written Question- 11604. http://www.parliament. uk/business/publications/written-questions-answers-statements/written-question/Commons/2015-10-13 $/ 11604$.

University of Bristol, Personal Finance Research Centre. (2013). The impact on business and consumer of a cap on the total cost of credit. Available at https://www.gov.uk/government/publications/the-impact-on-businessand-consumers-of-a-cap-on-the-total-cost-of-credit.

Watson, M. (2005). Foundation of international political economy. Basingstoke: Palgrave Macmillan.

Watt, N., Wintour, P. (2012). Payday loan firms face cap after government U-turn. The Guardian. http://www. theguardian.com/money/2012/nov/28/payday-loan-cap.

Weber, M. (1964) (1947- the First Free Press paperback edition). The theory of social and economic organisation (A. M. Henderson and T. Parsons (trs)). Oxford: Oxford University Press.

Weber, M. (1978). Economy and Society. In G. Roth \& C. Wittich (Eds.), Economy and society, volume I. California: University of California Press.

Williamson, O. E. (2000). The new institutional economics: Talking stock, looking ahead. Journal of Economic Literature, 38(3), 595-613.

Wonga (2016). www.wonga.com. 